\title{
Refining Traditional and Modern:A Literary Study of Indonesian Sufism and Neo-Sufism from Pesantren
}

\author{
Yuyun Sri Wahyuni \\ Mulawarman University Indonesia \\ email:yu2nsriwahyuni@yahoo.com
}

\begin{abstract}
Scholars have predicted that Sufism and other forms of traditional Islamic practices would disappear as modernity comes into society. Considering this view on religion and the modern, based on the literary study, this paper examines the historical development of Islam, Sufism, and pesantren in Indonesia, or previously known as Nusantara. Sufi preachers, known as walisongo, brought Islam to Indonesia and in a very short of time brought most of Indonesians into voluntary conversions. After walisongo, Indonesian ulama carried the dakwah Islamiyah through different Sufi networks and pesantrens. In the modern era, Sufism and other means of traditional practices face the challenges of disappearance and then transform themselves into neo-Sufism. The discussions in this paper show how Sufism, through its various ways, mingle with the different era in Indonesia and reshape the meaning of traditional and modern in Indonesia.
\end{abstract}

\section{Keywords:}

Islam Indonesia, Sufism, and pesantren

\section{Introduction}

In current understanding of modernity, segregation between modern secular and traditional religious subsists clearly. Recently, most of western liberal-secular countries define religious life of groups and individuals as private matters separated from public life spheres. This secularization is regarded as a result of long modernization process of philosophy and science. In such modernistic perspective in western- 
secular countries, religion and spirituality that stemmed from non-logic traditions are considered as pre-modern and experiment-based rationality (positivism logic). Religion and spirituality are regarded as modern, and some consequences for this view, it is a common view currently that religion and the public should be separated (Casanova 2007; Bruinessen 199; Murphy 2010; Kara 2016; Wilson 2017).

Following this development, scholars predict that along with modernity, religion and other means of spirituality would disappear. However, in Sufism and the Modern in Islam, Bruinessen and Howell (2013) explain that in Indonesia and several other countries, where the economic development is not as gigantic as in the Western countries, religion (Islam) exists and, more than that, the people consider most spiritual religious aspects (Bruinessen \& Howell 2007). One of the examples is traditional Sufism which has mingled very well with the modern. Some findings of the new studies of Sufism are regarded as challenging the theory of religious disappearance in modern and postmodern era.

This paper studies the development of Sufism in Indonesia, which is richly influenced by pesantren. Explaining the changes and continuation of pesantren and Sufism from time to time in Indonesia based on literary data from literary study, this paper argues:(1) pesantrens maintain the existence of Sufism among Indonesian traditional and modern societies, (2) pesantrens make the principles of Sufism as the common ground between Muslims traditionalists and modernists Muslim in Indonesia, and (3) the Indonesian Islam history and development show that the common conception of traditional and modern need to be revisited, if not redefined.

\section{Islam in Nusantara:A Historical Account}

Nusantara, also known as South East Asian Malay archipelago, today is located at the intersection of two trading zones in the past, Indian 
Ocean and South China Sea. Because of this location, it played important roles for international silk routes in the modern antiquity era (Riddell 2001; Azra 2006; Laffan 2011).

Islam came in Nusantara through global lines. There are opinions that early Muslim in the region spread the Islamic dakwah, but along with other scholars, Laffan (2011) argues that Islam was a late arrival as a religion of the state.

Dhofier (2011) and Andaya (2001) narrate that Barus in Sumatra was the famous international cosmopolitan port in the mid of $10^{\text {th }}$ to $15^{\text {th }}$ c. Reid in Dhofier says that Barus was famous with its best camphor exports. Camphor represented expensive perfume preferred by the leaders in big kingdoms. Being the kings and queens' favorites, camphor was really expensive, and that was why only rich sellers with big capital could run camphor business (Dhofier 2011). Scholars believe that there were not only traders who came to Nusantara in this era of commerce but also Muslim preachers. In addition, Dhofier mentions that the Indonesian traders who converted to Islam continued the tradition of amaljariah in which they invited Muslim teachers to sojourn Barus. Barus then became the center of trade and Islamic religious learning.

According to A.H. Johns (1961) during this era of commerce, Arab traders called camphor as Barus Fansuri. This name was a combination of camphor product with a Sumatran well known Muslim Sufi scholar, Hamzah Fansuri. Hamzah Fansuri was a distinguished Malay Muslim scholar in Barus. In his late age, Hamzah Fansuri moved to Mecca and became the Imam of Masjidil Haram. He then passed away in Mecca in the $16^{\text {th }}$ c. and was buried in Bab al Mala, the cemetery complex of the Prophet Muhammad's family and companions. In Muslim Mecca's tradition, it is only distinguished Muslims and Muslim scholars who buried in Bab al Mala. There were numbers of Fansuri's students who became the renowned Muslim scholars. Some names, such as Syamsuddin as Sumatrani, 
Abdurrauf as Singkili, Nuruddin Ar-Raniri and Syekh Nurullah, narrated in their works that they are Hamzah Fansuri's students. When Fansuri moved to Mecca, he asked Nurullah to move to Demak, and affiliated with the nine saints or walisongo. In Dhofier, it is mentioned that in his works, Hamzah Fansuri wrote lots of notions on walisongo, and most of his accounts on walisongo reflected his proud on them for their Islamizing the whole Java in short period. Scholars regard that it is not Islamization process that made Indonesia the biggest Muslim country today. Instead, it was voluntarily conversion among Indonesian non-Muslims into Islam through walisongo and Sufi preachers' efforts of bringing Islam close to people's realms (Dhofier 2011; Wieringa 2006).

In a Nahdhatul Ulama book discussion on the history of Islam in Indonesia in Berlin (http://www.youtube.com/watch?v=KIZsbtFmigM), Siswo Pramono argues that Sufi preachers who came to Nusantara realized that they came to a place where big old civilizations and kingdoms existed for thousand years. Thus, changing the whole system into totally new constructions would not significantly and peacefully transform society into Islamic values. Considering this, in genius ways, the Sufi preachers utilized local cultural traditions to bring people into Islam. This statement goes along with the genius of Walisongo in spreading Nusantara Islam. Walisongo word is a combination of Arabic and Javanese term. Wali is derived from Arabic terminology waly which means the friends of God and songo is derived from Javanese word means nine. Walisongo refers to nine numbers of wali who Islamized Java. Laffan (2011) mentioned that all the nine walis are the descendants of Prophet Muhammad. Scholars argue that in their engagement with the dakwah Islamiah in Nusantara, Walisongo did not affiliate with any of tareqat institutions, such as Qadiriyah, Naqshabandiyah, or other thareqat institutions. However, they significantly used the principles of Sufi spirituality and Islamic mysticism. Laffan (2011) narrates that in Indonesia prior to the $16^{\text {th }} \mathrm{c}$. in local epics including 
in Babad Tanah Jawa, Walisongo were depicted as having supernatural powers. The saints or walis, as understood in Sufism, refer to those who are given with special knowledge and capabilities or karamah. Different literatures explains that in their dakwah activities, Walisongo brought Islam close to people's realms and some scholars argue that in this process, Indonesians themselves chose to be Muslims. Hooker in Laffan (2011) argues that through such a way, without neglecting the global Islamic dimensions, Islam was indigenized among Indonesians (Laffan 2011).

In his work, Laffan also explains Islam in Indonesia is brought and developed in Sufi ways. He narrates that in the book of Abdallah bin As'ad al-Yafi'i (the writer of Abd Qadir al-Jilani's life record), in the $14^{\text {th }}$ c. during his youth he saw a Jawi man who was called Mas'ud al-Jawi attended and was in the Qadiriyah fraternity circle. This record by al-Yafi'i supports the theory of the spread of Islam in Indonesia in the hand of tariqa syuyukh by A.H. Jones. Through his works, A. H. Jones (1961) argues that Sufism was a functional and typifying category in Indonesian social life, which left clear evidence of itself in Indonesian letters between the $13^{\text {th }}$ and $18^{\text {th }}$ centuries. It was directly involved in the spread of Islam to Indonesia, it played significant part in the social organization of the Indonesian port towns, and it was the specific nature of Sufism which facilitated the absorption of non-Muslim communities into the fold of Islam. According to Laffan, the spread of Islam was massive in this era and Islamic civilization was high in Nusantara. Laffan further says that Aceh Sultanate in the era of Hamzah Fansuri and Syamsuddin Ar-Raniri with their Sufi perspective was the center of power, learning and international trade in its time. $\mathrm{He}$ also regards that Aceh was equated with the Ottoman Empire.

\section{Sufi Networks and Pesantren}

Since Islam came and developed in Nusantara, there were waves of Malay and Hadrami descendants travelled to Mecca for pilgrimage. 
The long voyage to Mecca made them interact each other on board and learn more about Islam. The significant periods they took for the voyage made them stay in the Middle East longer after they were done with their bajj. During this stay, they learned about Islamic religious matters from different teachers in Mecca and other surrounding areas in the Middle East. Such forms of Islamic learning experiences on the ships to Mecca and in different Middle East countries enabled those bujaj (plural form of hajj: pilgrims) to become religious experts and held the positions as Islamic preachers in their communities when they returned (Azra 2002; Rosnani Hashim 2010). Upon their return, they established different forms of tarekat organizations referring to the global transnational orders in Mecca and other areas such as Qadiriyyah, Naqshabandiyah, Syattariyah, etc. and they also built pesantrens (Dhofier 2011). Since the establishment of pesantrens, most of them became the locus of tarekat. However, some pesantren applied tarekat without necessarily formed tarekat order or affiliated with it (Zulkifli 2002). Rinkes in Dhofier, states that the Satariyah order was first brought and developed by Abdurrauf as-Singkili in Sumatra and this order was then spread into West Java and Central and East Java by Abdul Muhyi, the student of As-Singkili. The similar narratives were applied to Qadiriyah order and Naqsyabandiyah order in the archipelago.

The tradition of thalabu al-ilm and Islamic dakwah were continued up to the Dutch colonial era in Nusantara. Their absence of knowledge and their anxiety about Islam made the Dutch limit the numbers of hujaj. Scholars mention that the increased numbers of bajj every year at that time also made the Dutch strictly regulated the pilgrimage activities (Azra 2002; Dhofier 2011; Zulkifli 2002; Aziz et al. 2017). This haij regulation, however, did not affect the increased numbers of the bujjaj so that the waves of the hajj even added the Dutch curiosities as well as worries of the development of Islam in the archipelago (Steenbrink, 1984; Benda, 1958). 
There were number of students from South East Asian regions such as Java, Makassar, Banjarmasin, Sambas, Pattani, etc. who committed this long traditions of coming to Middle Eastern doing pilgrimage and committing themselves on thalab al-ilm for years. According to Snouck Hurgronje in Dhofier, the numbers of Nusantara bujaj in the time when he went to Mecca for six months were more than 5000 people. All this 5000 were students. Students from Nusantara iSten Mecca that time were more than half of the whole numbers of foreign students in it.

Azra (1999) mentioned that although Nusantara students in Mecca came from different places in archipelago, they were commonly referred as Malay and Jawi. Malay referred to those who came from outer Java Island while Jawi to Javanese. Dhofier (2011) mentions that big number of Indonesian bujaj and knowledge travelers brought different kinds of classical literatures to be taught in tarekat and in pesantrens. These varieties of literatures are until today termed as kitab kuning or the classical yellow books. Such great variety of classical literatures taught in pesantren is the main reason why Indonesian Muslims today are importantly plural (Dhofier 2011; Bruinessen et al. 1994).

The tradition of baij and thalab al-ilm among Indonesians did not stop in the $18^{\text {th }} \mathrm{c}$. but were continued and strengthened throughout the $19^{\text {th }}$ c. Syekh Ahmad Khatib Sambas, Indonesian Malay teacher in Masjid al-Haram in $19^{\text {th }} \mathrm{c}$. was regarded as one of the main figures in shaping Indonesian Sufism history. He was the founder of Tarekat Qadiriyah wa Naqsyabandiyah (TQN). S.N. Al-Attas and Kartodirdjo in Dhofier explain that from the middle of the $19^{\text {th }}$ to the middle of the $20^{\text {th }} \mathrm{c}$. TQN played the most important role in spreading Islam in Indonesia and Malaysia. Among the books that Syekh Ahmad Khatib Sambas authored is Fath alArifin, which comprises drikerguidelines for the tareqat order. The common consideration among Indonesian knowledge seekers in Mecca was that their study periods were not considered as complete until they studied 
with Syekh Ahmad Khatib Sambas. The founder of Muhammadiyah, the Muslim modernists organization, K. H. Ahmad Dahlan, and the founder of Nahdhatul Ulama, K.H. Hasyim Asy'ari are among the well-known students of Syekh Ahmad Khatib Sambas. Syekh Ahmad Khatib Sambas was well respected due to his high level of knowledge, not only in Sufism but also in other Islamic science. This fact, as Hurgronje said in Dhofier, opposes the European scholars' understanding on Muslim scholars opposing tarekat in Indonesia. Howell's (2001) narration on how Sufism values, with or without tarekat, are preserved among Indonesians through pesantren, as the center of Muslim scholars in Indonesia, also opposes the idea of Sufism being marginalized among Muslim scholars(Bruinessen \& Howell 2007).

Sufism in Nusantara was divided into two mainstreams of Sufism. They are the Philosophical Sufism that seeks unity with the Eternal Reality, such as that inspired by Al-Hallaj and Ibn Arabi etc., and the orthodox Sunni Sufism influenced by Al-Ghazali. Both kinds of Sufism were developed among Indonesian societies either from tarekat or from pesantren and both kinds of Sufism in Nusantara, as many Indonesian and westerner scholars suggested, were not the passive inward led Sufism. Through tarekat and pesantren, Sufism became the locus for religious and political literacy among Indonesians. The idea of religious orthodoxy and the State's interests upon modernizing its people, however, made philosophical Sufism that mingled a lot with Indonesian indigenous mysticism marginalized and do not get much support compared to the orthodox Sufism.

\section{Challenges on Sufism in the Modern Indonesia}

In her article, Sufism and the Indonesian Islamic Revival, Howell (2011) narrates that Sufism in Indonesia faced challenges from both the Wahabists and the modernists. Wahabi considered that Islam needed to be 
purified from the un-Islamic practices such as tombs visits, and etc., which are common among Sufi followers. Along with this, in Muslim modernists' perspective, Sufism is among the main reasons why Islamic civilization was diminished. Modernists suggest that with Islam's rationality spirits and without its mystical (and sometimes) spiritual aspects, Islam can exceed the world civilization. Even though the roots of Islam and modernization thought came to Indonesia since the $17^{\text {th }}$ c. (Azra 1999), this modernist's challenge on Sufism was institutionalized in Indonesia in the beginning of the $20^{\text {th }}$ century.

Among the first Muslim modernists' organizations in Indonesia that was established during this time, and it still exists until today, is Muhammadiyah. Muhammadiyah was founded in 1912 after K. H. Ahmad Dahlan finished his study in Mecca and returned to Indonesia. When he was in Mecca, he learned from different teachers including from the famous Ahmad Khatib Sambas. K. H. Ahmad Dahlan was also influenced much by the thoughts and teachings of Hasan Albanna in Egypt on Islam modern reform movement. The conditions of Indonesian Muslims which, in K. H. Dahlan's view,was affiliated too much to mysticism and syirk, made K.H. Dahlan initiated changes and purification on Islam in Indonesia (Nugraha 2009). Among the values and characters of Muhammadiyah that are maintained since its establishment is that Muhammadiyah bases its dakwah movements on the spirit of Islamic reform or tajdid. Ideas and activisms of this organization are aimed to purify Islam from the un-Islamic practices such as syirk, khurafat and bid'ah' (http://www.muhammadiyah.or.id).

1 In Indonesia today, among Muhammadiyin, the notions of syirk, bid'ah and khurafat are well known and abbreviated as TBC that is tahayyul (belief in others' power other than Allah's supremacy), bid'ah (religious practices innovations which are not based on the Qur'an and the Hadits) and khurofat (beliefs on popular un-Islamic stories and prohibitions that are regarded as Islamic). 
Responding to the challenges espoused by Wahabists and Muslim modernists and defending the forms of cultural Islam ${ }^{2}$ among Indonesians as well as among global Muslim, Indonesian Muslim scholars who were commonly Sufism affiliates, organized themselves in Nahdhatul Ulama (NU). In the beginning of the $19^{\text {th }}$ century, Indonesian Muslim scholars who led pesantren actively spread the consciousness to oppose the Dutch colonialism among Indonesian Muslims. In 1916, they formed Nahdhatul Wathan, and in 1918 they established Tashwirul Afkar or Nahdhatul Fikr. Through these two organizations, Muslim scholars provided religious and political educations for their santri (pesantren attendants). Other than those mentioned organizations, Muslim scholars founded Nahdhatut Tujjar, a Muslim organization that was initiated to strengthen the grassroots economic conditions (http://www.nu.or.id).

The founding of these different organizations was inspired by the emerging awareness among Indonesians to oppose Dutch colonialism through modern organizations. Pramoedya Ananta Toer in his Buru Quartet ${ }^{3}$ narrates that Minke, his narrative figure that represents the real Indonesian figure, Tirto Adi Suryo-the father of Indonesian Journalism, aroused awareness among Indonesians that there were no other ways to end colonialism in the archipelago except with modern organization. The first indigenous organization representing Indonesian proto nationalism

2 Cultural Islam is the term used for Islam that promotes cultural indigenous identities as long as it does not oppose the teachings of Islam. Cultural Islam is also used to represent different expressions of popular Islam among Muslims especially in Indonesia. Cultural Islam is mainly used to oppose the idea of Arabization of Islam, such as that is promoted in Wahabi movements.

3 Buru Quartet is sets of novel written based on Indonesian modern historiography during the Dutch colonialism. This quartet was written when Pramoedya was jailed in Buru Island for his critical accounts on Suharto regime. This quartet was banned during the New Order regime for it is considered as dangerous for national stability assigned by Soeharto. The four novels are: Bumi Manusia (This Earth of Mankind), Anak Semua Bangsa (Child of All Nations), Jejak Langkah (Footsteps), and Rumah Kaca (House of Glass). 
was Sarekat Dagang Islam (SDI) that transformed into Sarekat Islam. SDI was founded in 1902 by Tirto Adi Suryo (TAS) and Samanhudi. TAS and Samanhudi successfully made Sarekat Islam as the uniting elements among Indonesian Muslims' struggling over the Dutch colonialism despites there were hostile oppositions and demolition on this organization from the Dutch. Through SDI and then SI, along with different Muslim modernists' organizations, pesantren scholars were really involved in elevating Indonesians conditions that were badly marginalized by the Dutch.

In 1920s, the Ibn Sa'ud King planned to make Wahabi as the sole madrhab (Islamic cult) in Hijaz (Mecca). With this wahabi insight, the Saudi kingdom destroyed lots of historical sites before and after Islam came. The tombs of the Prophet Muhammad's families and companions were closed, and visiting the saints' graveyards was highly considered as bid'ah. This idea of Wahabism was agreed by Indonesian Muslim organizations. However, pesantren scholars opposed this idea (Khulq 2000). Due to their different perspectives on this matter, pesantren scholars were banned from the congress of Al-Islam in 1925 in Jogjakarta. Consequently, their absence from this congress made them lose their aspirations before the Mu'tamar 'Alam Islami (International Islamic Congress) on the madrabib in Mecca. Based on the motivation of defending different madzabib existences in Mecca and preserving the cultural Islamic expressions in global Islam, pesantren scholars formed their own delegations to Mu'tamar 'Alam Islami, which is named Hijaz Committee led by K.H. Wahab Hasbullah. The Hijaz committee successfully negotiated with Ibn Saud King. As a result, Mecca did not ban different Muslim madzhahib practices in it. The Hijaz committee was then developed into traditional Muslim organization, Nahdhatul Ulama (NU) (Khuluq 2000).

In its social religious activism, NU and its affiliated institutions defended forms of Sufi practices among Indonesian Muslims while Muhammadiyah and other modernist organizations stood for the 
opposite axis that is prohibiting the practices of Sufism. This oppositional standpoint brought the long history of oppositions between these two largest Muslim organizations in Indonesia. The massive attempts of Islam reform movements by Muslim modernist organizations in Indonesia and the huge economic development programs by Indonesian New Order government (1965-1998), made scholars predicted that the forms of Islam spiritualism or Sufism in Indonesia would decline, if not disappear. Through her research on Indonesian Sufism, Howell (2001), however, rejects the idea on the decline of Sufism in Indonesian's era of modernity.

In Sufism and the Modern in Islam edited by Howell and Bruinessen (2007), it is argued that Sufism persisted and revived in different parts of Islamic hemisphere. The book also suggests that through different compliances in its different contexts, Sufism encounters the challenges of Islamic modern reform movements and Islamic revivalism. In Indonesia part, in his article, Bruinessen explains that historically, as well as politically, Sufism played significant roles in shaping Indonesian Islam. This idea of Sufism and political activism are also mentioned in Yosuko's (1997) notes on Kyai and Japanese Military. Yosuko narrates that K.H. Hasyim Asy'ari, pesantren leader and Sufi greatly contributed to Indonesian independence from the Dutch and then from Japan. Sufism locus such as tarekat and pesantrens do not only serve as the habitus of Sufism but also spread the idea of Islamic spiritualism and social political awareness among Indonesian Muslims in general (Bruinessen \& Howell 2007; Bruinessen et al. 1994; Musso 2017; Millani et al. 2017).

Examining the history of how Islam came and became the major religion in Indonesia, practices of Sufism among Indonesian Muslims are common. In addition, Sufi's direct or indirect involvements in Indonesian national political activism in pre and post-independence made Sufism gain special places among Indonesian elites currently. Other than that, pesantrens as the oldest form of Islamic school and education maintain 
the teachings and values of Sufism among its people through its kitab kuning or Islam classical literatures (Bruinessen et al. 1994). Pesantrens's alumni, who commonly pursue their religious education in pesantren as the continuation of the old traditions of thalab al-ilm among Muslim scholars in Nusantara, absorb the teachings of Sufism and spread it among communities in their different places of origins. Some pesantrens like pesantren Suryalaya affiliated to specific Sufi Order and taught its santri to become the followers of the order (Millie 2006). The other pesantren, like pesantren Tebu Ireng preserves the values and teachings of Sufism without being affiliated into specific tarekat order. In his life, the founder of pesantren TebuIreng was a Sufi practitioner but he did not promote tarekat preaching in his pesantren (Misrawi 2010).

According to Howell (2001), there are three main reasons why Sufism revived in Indonesia. First, the existence of Nahdhatul Ulama that insists on applying almuhafadzoh' 'ala al-qadim al-sholih wa al-akhdzu bi al-jadid al-ashlab or a firm hold on the old truth principles and open mind stances to take the benefits of contemporary values in their socio religious activism, influences the existence of Sufism practices in Indonesia as the elements of qadim al-sholih among Muslims. Second, the challenges of modernism compel Sufism to reevaluate their old ways of fraternity. As that of Sufism adaptations of the modern in Senegal (Glover 2007), Indonesian Sufi Orders widen their methods of members' recruitment into the fraternities without neglecting the principles of their Sufi Orders. Howell shows that in 1980s Indonesian tarekat order changed their method of recruiting followers. Beside their traditional strict Sufi Order, tarekat expanded their activities into community reach out in public access. In Indonesia today, massive religious gathering for congregational prayers led by Sufi leader oriented is common in different places. Tarekat and Sufi followers also open their access to academic and modern means of member recruitment such as university lectures, radio and TV talk shows (Bruinessen \& Howell 
2011). Third, the Islamic reinterpretations endorsed by both NU and Muhammadiyah scholars play important roles. Abdurrahman Wahid and Nurcholis Madjid are two figures that represent most on modernizing the thoughts of Islam and religiosity in Indonesia. They both promote a more open religious interpretation towards Islam. Nurcholis Madjid's views on Neo Sufism, which accelerate Hamka's thoughts on Modern Tasawuf or modern Sufism and Fazlurrahman Neo Sufism, make Muhammadiyah reconsider their views on religious reform movement. In his thought, Nurcholis Madjid considers religious modernization that they support make their religiosity empty from spiritual inquiries that are vital in Islam (Kuswanto 2007). Through this kind of dynamic, Muhammadiyah, as Howell explains, tolerates aspects of Sufism spirituality.

\section{Indonesian Sufism and Neo Sufism from Pesantren}

Scholars agree that pesantren is the oldest form of educational institutions in Indonesia. Pesantren was the primary educational system for Muslims in Indonesia and played important roles in centuries before modern educational institutions established in it (Dhofier 1999; Tahir 2017; Makbuloh 2017; Mohd Nor et al. 2017). In its development, Indonesian pesantrens are mainly categorized into two types; they are traditional pesantren and modern pesantren. Traditional pesantren represents a pesantren that only teaches Islamic subjects in its curriculum. The subjects taught are mainly based on classical Islamic literatures. Some of this pesantren, however, add sciences and other secular subjects but maintain the teachings of classical literatures. Modern pesantrens consider the teaching of Islamic theology based on limited classical literatures is not enough for younger generation to meet the challenge of modernization. In order to be a good God khalifah on earth, Muslim should be able to manage all aspects of life inquiries, which needs contemporary life and social science. Thus, modern pesantrens teach their students both Islamic spirituality and modern subjects. 
Indonesian traditional pesantrens, as mentioned in previous chapters, preserve the values of Sufism through practicing tarekat with or without the bound of tarekat orders. Modern pesantrens, on the other hand, suggest Muslim to be modern without necessarily leave the spirituality of Islam. It strongly requires Muslim learners to be both religious and modernized. Among the references that are used to support such view in modern pesantren is the famous hadith among Muslim narrated in Bukhori and Muslim: "who wants the world he/she should have the knowledge of it, who wants the hereafter he/she must possess the knowledge of it, and who wants both the world and the hereafter he/she should acquire both knowledge of the world and hereafter." Since 1926, the first modern pesantren in Indonesia, Gontor, has taught the subjects that cover both Islamic and secular subjects. Such values taught in modern pesantren are mainly originated from the thoughts of similar to neo Sufism. It has not been studied yet whether Indonesian neo Sufism influenced modern pesantren or it is modern pesantren practices of Islamic spirituality that inspire the thought of Indonesian neo Sufism or tasamuf modern.

Both traditional and modern pesantrens requires its santris or pesantren students to go back to their societies and serve as society's reminders of the good values. This tradition is mainly taken from the Qu'ran surah At Taubah 122:

"And it does not beseem the believers that they should go forth all together; why should not then a company from every party from among them go forth that they may apply themselves to obtain understanding in religion, and that they may warn their people when they come back to them that they may be cautious?" (www. alquranenglish.com).

Agreed interpretation on this verse among Muslim scholars suggests that seeking knowledge is mandatory for Muslims and applying the gained knowledge for society is equally obligatory. From such understanding of Islam and knowledge, traditional and modern pesantren alumni, who stay in different places in Indonesia, apply what they understood from 
Sufism and neo Sufism into their societies. From this process of pesantren alumni's involvement in Indonesian Muslim society, Indonesian Muslims commonly are well acquaintance if not practicing Sufism or Neo Sufism.

Historical accounts on Indonesian traditional and modern on Islam explained in different chapters in this paper show that the definition of what is modern and what is traditional among scholars needed to be revisited. This paper argues that being modern does not necessarily eliminate the aspects of traditional identities that are preserved, and vice versa, being traditional, does not completely neglect the aspects of modern in this contemporary life. The ways Indonesian Muslims articulate whether they are being traditional or modern through Sufism and Neo Sufism show how religion stays in the modern and how the modern needs to be redefined.

\section{Conclusion}

Modernists have predicted that spirituality would disappear as the consequence of modern life. This modern scholarly view as described in this paper is not valid. Sufism, the considered heart of Islamic spirituality stays and intersects with modernizations. In Indonesian Muslim historiography, Sufism played and still plays important roles in defining historical, cultural and political aspects of social life. Sufism in its different adaptations to the modern does not lose its significant identities as Islamic spirituality. Indeed, pesantrens as the basis of Islamic education in Indonesia supports the existence of Sufism among Indonesians. 


\section{References}

Aziz, N.S., Ismail, A.S., Mohidin, H.H.B. 2017. Building Communal Values for Quality Sustainable Living in Traditional Madrassa-The Case of Madrassa Quran Kubang Bujuk, Trengganu. Advanced Science Letters 23 (9), pp. 8384-8388.

Azra., A. 1999. Jaringan ulama: Timur Tengah dan kepulauan Nusantara abad XVII dan XVIII : melacak akar-akar pembaruan pemikiran Islam di Indonesia. Bandung: Mizan.

Azra, A. 2002. Islam nusantara, jaringan global dan lokal. Bandung: Mizan: Didistribusikan oleh Mizan Media Utama.

Azra, A. 2006. Islam in the Indonesian world: an account of institutional formation. Bandung: Mizan.

Benda, H.J. 1958. The Crescend and Rising Sun, Indonesia Islam under The Japanesse Occupation of Java. The Hague: W. Van Hoeve.

Bruinessen, M. van., \& Howell, J. D. (2007). Sufism and the "Modern" in Islam. U.K. I.B. Tauris. Retrieved from http://handle.uws.edu. au: $8081 / 1959.7 / 510284$

Bruinessen, M. van, Marschall, W., \& Studies, E. C. on I. and M. (1994). Pesantren and kitab kuning: continuity and change in a tradition of religious learning. Texts from the Islands : Oral and Written Traditions of Indonesia and the Malay World, 121-145.

Casanova, J. 2007. Rethinking secularization: A global comparative perspective. In Religion, globalization, and culture (pp. 101-120). Brill.

Dhofier, Z. 2011. The pesantren tradition: the role of the Kyai in the maintenance of traditional Islam in Java. Tempe, Ariz.: Monograph Series Press, Program for Southeast Asian Studies, Arizona State University.

Glover, J. 2007. Sufism and Jihad in Modern Senegal: The Murid Order. Rochester, NY: Rochester University Press.

John, A.H. 1961. Sufism as a Category in Indonesian Literature and History. JSAH 2, July: 10-23.

Kara, D.S. 2016. Conflict Between Traditional and Modern Muslim Practices. Acta Ethnographica Hungaria 61 (2), pp. 469-481. 
Khuluq, L. 2000. Hasyim Asy'ari religious thought and political activities (18711947). Ciputat, Jakarta: Logos.

Kuswanto, T. A. 2007. Jalan Sufi Nurcholish Madjid: neo sufisme. Papringan, Yogyakarta: Pilar Media. Retrieved from http://books. google.com/books?id=KVPYAAAAMAAJ

Laffan, M. F. 2011. The makings of Indonesian Islam: orientalism and the narration of a Sufi past.

Makbuloh, D. 2017. Process, Result, and Consequence of Madrassa Accreditation: A Case Study in Lampung, Indonesia. Advanced Science Letters 23 (2), pp. 948-952.

Milani, M., Possamai, A., Wajdi, F. 2017. Branding of Spiritual Authenticity and Nationalism in Transnational Sufism in Religion, Nations, and Transnationalism in Multiple Modernities, pp.197-220.

Millie, J.P. 2006. Splashed by the Saint: Ritual Reading and Islamic Sanctity in West Java. Leiden: KITLV Press.

Misrawi, Zuhairi. 2010. Pandangan Muslim Moderat Toleransi, Terorisme, dan Oase Perdamaian. Jakarta: Kompas Media Nusantara.

Mohd Nor, M.R., Senin, N, Mohd Khambali Hambali, K., Ab Halim, A. 2017. Survival of Islamic Education in a Secular State: The Madrassa in Singapore. Journal for Multicultural Education 11 (4), pp. 238-249.

Musso, G. 2017. The Making of Fragmanted Nation: Sufi Turuq and Sudan's Decolonization. Oriente Moderno 97 (1), pp. 133-153.

Murphy, D. 2010. Between Socialism and Sufism: Islam in the Films of Ousmane Sembene and Djibril Diop Mambety. Third Text 24 (1), pp. 53-67.

Nugraha., A. 2009. K.H. Ahmad Dablan : biografi singkat, 1869-1923. Sleman, Jogjakarta: Garasi : Didistribusikan oleh ar-Ruzz Media.

Riddell, P. G. 2001. Islam and the Malay-Indonesian world: transmission and responses. London: Hurst [u.a.].

Rosnani Hashim. 2010. Reclaiming the conversation : Islamic intellectual tradition in the Malay Archipelago. Kuala Lumpur: The Other Press.

Steenbrink, Karel. 1984. Beberapa Aspek tentang Islam di Indonesia Abad ke19. Jakarta: Bulan Bintang. 
Tahir, S.Z.B. 2017. Multilingual Teaching and Learning at Pesantren Schools in Indonesia. Asian EFL Journal 2017 (98), pp.74-94.

Van Bruinessen, M. 1995. Muslim Fundamentalism: Something to be Understood or to be Explained away?. Islam and Christian-Muslim Relations 6 (2), pp. 157-171.

Wieringa, S. E. 2006. Islamization in Indonesia: women activists' discourses. Signs: Journal of Women in Culture and Society, 32(1), 1-8.

Wilson, M.B. 2017. The Twilight of Ottoman Sufism: Antiquity, Immorality, and Nation in Yakup Kadri Karaosmanoglu's Nur Baba. International Journal of Middle East Studies 49 (2), pp. 233-253. Zulkifli. 2002. Sufism in Java: the role of the pesantren in the maintenance of sufism in Java. Leiden [etc.]: Indonesian-Netherlands Cooperation in Islamic Studies (INIS). 
DINIKA, Volume 2, Number I, January - April 2017 